\title{
Esophageal Reconstruction with the Stomach, a Functional Dilemma?
}

\section{Dragos Predescu, Silviu Constantinoiu}

General and Esophageal Surgery Department, Center of Excellence in Esophageal Surgery, Sf. Maria Clinical Hospital, Bucharest Carol Davila University of Medicine and Pharmacy, Bucharest, Romania

Corresponding author: Dragos Predescu MD

General and Esophageal Surgery Department, Center of Excellence in Esophageal Surgery, Sf. Maria Clinical Hospital, Bucharest 37-39 Bdul Ion Mihalache, district 1 Bucharest, Romania

E-mail: drpredescu@yahoo.com

\section{Rezumat}

\section{Reconstructia esofagiană cu stomacul, o dilemă functională?}

În urmă cu câteva decade, substituția esofagiană se adresa în special cazurilor de stenoze esofagiene postcaustice; actual, reconstrucția şi-a lărgit paleta indicației şi pentru alte domenii din patologia esofagiană benignă (tulburări motorii severe, acalazie multi-recidivată, stenoze peptice, etc.) dar a devenit şi un timp final cvasi-obligatoriu în exereza esofagiană pentru cancer ori de câte ori gestul este posibil. Tehnicile de reconstrucție esofagiană ce folosesc potențialul visceral al stomacului, indiferent de indicație şi varianta tehnică aleasă, rămân o metodă valoroasă şi eficace. O serie de argumente redutabile pledează pentru un tip sau altul de grefon gastric: factori anatomici mai mult decât convenabili (vascularizație, lungime suficientă, structură parietală competentă pentru sutură, etc.) şi un act operator sustenabil (durată, abord, complexitate timpi operatori, tulburări digestive post-grefare, funcționalitate postterapeutică, etc). Opțiunea pentru o tehnică sau alta, dincolo de argumente patologice, trebuie să țină cont de funcționalitatea la distanță, cu evident impact pe status-ul metabolic şi calitatea vieții. Deci putem argumenta functional un montaj gastric sau altul funcție de acest criteriu? In final, dovada unei rezolvări adecvate este relativ facil de apreciat: a fost restabilită deglutiția şi dacă da, rezultatul s-a menținut în timp? Pentru cazurile oncologice evaluarea trebuie să țină seama şi de criteriul cronologic al ratei de supravietuire postoperatorii.

Metodă: Lotul evaluat statistic s-a întins pe perioada 1981 - 2016 şi a cuprins un număr de 268 de pacienți operați pentru stenoze esofagiene, repartizați în funcție de etiopatogenie şi indicație în 201 de reconstrucții pentru cauze stenotice post-caustice şi 67 
pentru substituție post-ablativă de cauză neoplazică. Tehnicile utilizate pentru evaluarea funcțională la distanță au cuprins: prânz radio-opac, ex.endoscopic + biopsie, iar la cazuri cu modificări evidente $\mathrm{pH}-\mathrm{metrie} / 24 \mathrm{~h}$ şi manometrie şi excepțional scintigrafie cu alimente marcate.

Rezultate: Au fost identificate două tipuri de probleme: un tip particular de disfuncție neuromotorie a substitutului esofagian la 6 pacienți (1 reconstrucție tip Gavriliu şi 5 cu tot stomacul Nakayama), evacuarea grefonului fiind dificilă, întârziată, cu stază importantă şi disconfort alimentar (vărsături, inabilitatea alimentației, fenomene aspirative) respectiv o patologie de reflux - 8 bolnavi, fiind argumentată de o simptomatologie specifică, de prînzul baritat, de examenul endoscopic şi de examen-ul pH-metric. Refluxul avea un caracter alcalin la 7 pacienți, toți cu piloroplastie, $5 \mathrm{cu}$ tot stomacul şi $2 \mathrm{cu}$ procedeu Akiyama iar la $1 \mathrm{caz}$ cu procedeu Gavriliu refluxul era acid.

Concluzii: Stomacul este o obțiune redutabilă în substituția esofagiană. În ceea ce priveşte rezultatele la distanță se constată o funcționalitate bună, cu un status metabolic rezonabil. Cele două fenomene de care depinde funcțional grefonul - activitate secretorie şi activitate motorie - par a se restabili odată cu trecerea timpului dar acesta nu se produce concomitent, recuperarea fiind mult mai rapidă a funcției secretorii.

Cuvinte cheie: reconstrucție esofagiană, grefon gastric tip Nakayama, Akiyama, Gavrilium, complicații funcționale post-reconstrucție

\section{Abstract}

Background: A few decades ago, esophageal substitution was mainly dedicated particularly in postcaustic esophageal stenosis; currently, the reconstruction has expanded its palette of indications to other areas of benign esophageal pathology (severe motor disorders, esophageal achalasia with multiple relapses, peptic stenosis, etc.) but has also become a quasi-obligatory final time in the esophagectomy for cancer whenever it is possible. The techniques of esophageal reconstruction using the stomach, regardless of the indication and the chosen technical option, remain a valuable and effective method. A number of striking arguments advocate for one or another type of gastric graft: anatomic factors more than convenient (vascularization, sufficient length, a wall structure favorable for suture, etc.) and a sustainable surgical intervention (length, approach, complexity of the surgical steps digestive disorders after surgery, post-therapeutic functionality, etc.). Choosing a technique or another, beyond pathological arguments, should take into account remote functionality, with a clear impact on metabolic status and quality of life. So, according to this criterion, can we functionally justify a type or another of gastric restoration? Finally, the proof of an adequate solution is relatively easy to appreciate: has swallowing been restored and if so, the result has been maintained over time? For oncological cases, the assessment should also take into account the chronological criterion of the postoperative survival rate.

Methods: The statistically rated lot ranged from 1981 to 2016 and included 268 patients with surgical interventions for esophageal stenosis, distributed according to etiopathogenesis and indication in 201 reconstructions for post-caustic stenosis, and 67 for post-esophagectomy replacement for neoplasm. The techniques used for remote functional evaluation included: barium swallow, endoscopy + biopsy, and in cases with obvious changes $\mathrm{pH}$ measurement/24 $\mathrm{h}$ and manometry and, only in exceptional cases, scintigraphy with marked foods.

Results: two types of problems have been identified: a particular type of neuro-motor dysfunction of the esophageal substitute in 6 patients (1 patient with Gavriliu reconstruction and 5 with Nakayama reconstruction, using the whole stomach), with difficulty, delayed gastric graft evacuation, with major stasis and abdominal discomfort vomiting, inability to eat, aspiration phenomena) respectively a reflux pathology - 8 patients, being proved by a specific simptomatology, barium lunch, endoscopic examination and $\mathrm{pH}$-metric examination. Reflux was alkaline in 7 patients, all 
with pyloroplasty, 5 with whole stomach and 2 with Akiyama procedure; in 1 case with Gavriliu procedure the reflux was acid.

Conclusions: Stomach is a good option in esophageal substitution. Concerning the remote results, a good functionality is found with a reasonable metabolic status. The two phenomena on which the function of the graft depends - secretory activity and motor activity - seem to be restored in time but these does not occur concurrently, the recovery of the secretory function being much faster.

Key words: esophageal reconstruction, gastric graft type Nakayama, Akiyama, Gavriliu, functional post-reconstruction complications

\section{Introduction}

Numerous techniques of esophageal reconstruction have been described and used over time, many of which are subsequently abandoned or increasingly restricted. The 50s set the techniques for reconstruction by stomach tubularisation, a technique that later fallen into disuse in the same time with the use of the colon, in its various variants, a "supremacy" that seems to change over the past two decades. The spectacular increase in esophageal and eso-gastric neoplasia was the cause of this readjustment, as a reassessment of this attitude was observed by increasing the use of stomach as an esophageal substitute in various variants, especially in cases of neoplasia. here are three main methods of using the stomach: (i) whole stomach (Nakayama), (ii) with standard isoperistaltic gastric tube by resection of the small gastric curvature (Akiyama), (iii) with gastric tube anisoperistaltic (Gavriliu I and II) or iso-peristaltic. The first two options are mainly used in the postablative reconstructions for esophageal neoplasia, as well as substitutions in benign stenoses, including post-caustic, associated or not with esophagectomy (Kirschner technique). Gavriliu gastric tube reconstruction technique has an indication especially in benign pathology and especially in pediatrics. The use of the whole stomach reservoir has become the new Hooly Graal in the last century's esophageal substitution due to unquestionable advantages and in spite of relatively dramatic disadvan- tages. In the entire literature, whenever it is possible to choose one type or another of gastric grafting, there is a favorable opinion to the use of the whole stomach instead of tubularisation, with some arguments that seem decisive: a much easier technique, especially using staplers, no time of visceral section, shorter execution time, an isoperistaltic device and therefore the considerations of a superior propulsion activity with a much better functionality, with improved regurgitation, reflux or aspiration phenomena. Is this a correct, argued idea, or is it a consequence of an easy technical concept? A number of counter-arguments suggest that keeping the intraabdominal gastric reservoir would result in a better visceral static and a less affected digestion, as well as a minimal bulk impact of the tubular graft on the cord/pulmonary complex; these are important advantages offered by the stomach tube. At first glance, there seems to be a technical compromise vs. a functional one.

The motor behavior of the visceral digestive recognize a pattern with great similarities, regardless of the level or type of organ involved. To highlight the transposition induced motor changes, some physiological elements of physiology are required of normal, homeostatic conditions. The main elements of the digestive tract are the three specific cell types: enteric neurons, Cajal interstitial cells (CIC) and smooth muscle cells. Of course, the motorpropulsion force in the digestive tract is due to smooth muscle cell activity but, like other 
muscle systems, these cells are unable to co- $^{-}$ ordinate alone the visceral motility. The first level of motor coordination is assured by intrinsic activity that can generate slow motion, which can propagate along several centimeters and can generate contractile activity. These slow waves originate in specialized areas, populated with Cajal cells (CIC), which is called "pacemaker regions". In the digestive tract these regions are well defined and specifically localized. In the stomach, the pacemaker activity is generated in the space between the circular and the longitudinal muscular layer, from the gastric body to the pyloric region. Because the pacemaker located along the great curves has a much faster rate of discharge, its cells will "dominate" those located in the distal stomach. Because the pacemaker located along the grater curvature has a much faster rate of discharge, its cells will "dominate" those located in the distal stomach. CIC is the active element, characterized by a unique intracellular timing mechanism and having an ion conductivity potential that will generate slow-wave "pacemaker" current. CICs are electrically coupled to each other as well as with neighboring muscle cells. Slow waves generated in the CIC propagate along the CIC network and are passively driven by smooth muscle cells. The muscle cell does not have the property of directly producing and directing electric wave, but allows a number of dependent ion channels $\left(\mathrm{eg} \mathrm{Ca}^{2+}\right)$ to respond to slow depolarization waves. $\mathrm{Ca}^{2+}$ channels will therefore open, with $\mathrm{Ca}^{2+}$ penetration and generation of contraction. The oscillations of the membrane potential of the muscle cell as a result of the slow waves, will increase and decrease the activity of the $\mathrm{Ca}^{2+}$ channels. As a consequence, it will cause a natural, periodic contractile behavior of smooth muscle cells in regions of slow electric waves, the so-called motility pattern such as peristalsis. This explains the presence of contractile activity even in the absence of other regulating factors, CIC and smooth muscle tissue spontaneously performing electrical activity and coupling excitation with contraction.

The amplitude of slow waves and contractile force are modulated by the myenteric nervous system. A wide variety of excitatory factors or neural inhibitors can interfere with and modify the contractile response produced by slow waves from weak to strong. As an example, excitatory stimuli can increase the amplitude of slow waves by augmenting $\mathrm{Ca}^{2+}$ inputs, producing a much stronger contraction, or, in the case of inhibitory stimuli, activation of $\mathrm{K}^{+}$ channels with cell conduction suppression and decreasing the amplitude of slow waves and contractile forces. Among the factors that modulate contractile activity are hormones, paracrine substances, mediators of inflammation, etc.

There is a big difference between the normal physiology of the stomach to the physiology of the transplanted stomach with its variants. In other words, how will be the motor behavior of the gastric graft, taking into account the fact that it will have to maintain a peristalsis as little affected as possible. This means a functional result with optimal peristalsis and consequently minimal digestive damage. The question arises naturally why such an approach would be necessary and, if so, in what way?

On this ontogenetic motor behavior, it seems interesting to investigate changes in neural behavior in the "little brain" by electromiographic data, with a direct effect on the peristaltic activity of the stomach or its tubularization transplanted but maintained in transit by a surgical assembly in a variant of the neo-esophagus type, with a primary, undigested bowl content.

\section{Material and Method}

This paper presents the experience of the General and Esophageal Surgery Clinic, "St. Mary" Clinical Hospital, "Carol Davila" University of Medicine and Pharmacy Bucharest in the reconstructive treatment of the esophagus. The statistically evaluated lot (Table 1) ranged from 1981 to 2016 and included 268 patients with surgery for esophageal stenosis, distributed according to etiopathogenesis and surgical indication in 201 reconstructions for post-caustic stenosis and 67 for substitution after esofagectomy for malignant tumors. From these cases were 
Table 1. Reconstructive surgery for esophageal substitution

\begin{tabular}{lcc}
\hline Type of reconstruction & \multicolumn{2}{c}{ Type of ensemble } \\
\hline & Postcaustic & $\begin{array}{c}\text { Esophageal \& } \\
\text { EGJ cancer }\end{array}$ \\
\hline Gavriliu gastric tube type I or II & 27 & - \\
\hline Akiyama gastric tube & - & 13 \\
\hline Nakayama with whole stomach & 3 & 39 \\
\hline Other (colon, jejunum, etc.) & 171 & 15 \\
\hline & Total $-201 \ldots \ldots \ldots$ & Total - $67 \ldots \ldots$ \\
\hline & Total cases - 268 & \\
\hline
\end{tabular}

excluded other surgical options - Ivor-Lewis, Moreno-Gonzales, the jejunum and the colon 186 cases. In 82 cases, we used the gastric graft. In the Nakayama variants (Fig. 1) and Akiyama (Fig. 2) - 55 cases, we practiced pyloroplasty in 31 patients in the initial phase of the study, now giving up this technique.

\section{Results}

We do not make any reference to early postoperative complications, i.e. all morbidity events occurring within 30 days of post-reconstruction. The postoperative mortality index was reasonable, 2 of those with post-caustic reconstruction (IMA or rhythm disorder) and 5 cases with reconstruction after esofagectomy for malignancy (2 because pleuro-pulmonary complications and 3 fistulas). Regarding late complications, we will only present the functional ones that we considered to be installed, as the moment of occurrence, whenever they occurred more than 6 months after the surgery. Of the 82 patients with gastric reconstruction, only 80 came to follow-up at 6 months after surgery, 77 at one year, only 68 at two years, and 54 at three years. After this period, the patients returned randomly to the clinic. A possible explanation for reducing the number of controls in the clinic could come from oncological patients, in which the development/relapse of neoplasia may be a cause.

In terms of remote functional assessments, the techniques used included: barium meal, endoscopy + biopsy, and in cases with obvious changes $\mathrm{pH}$ measurement/24 $\mathrm{h}$ and manometry and, only in exceptional cases, scintigraphy with marked foods.

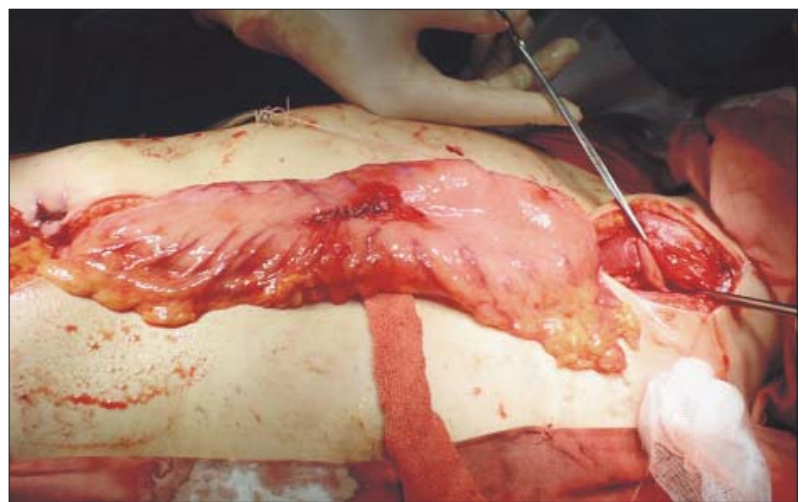

Figure 1. Nakayama procedure - intraoperative aspect - whole stomach reconstruction for severe post-caustic esophagitis, trans-hiatal esophagectomy. The site of gastrostomy sutured during surgery is noted

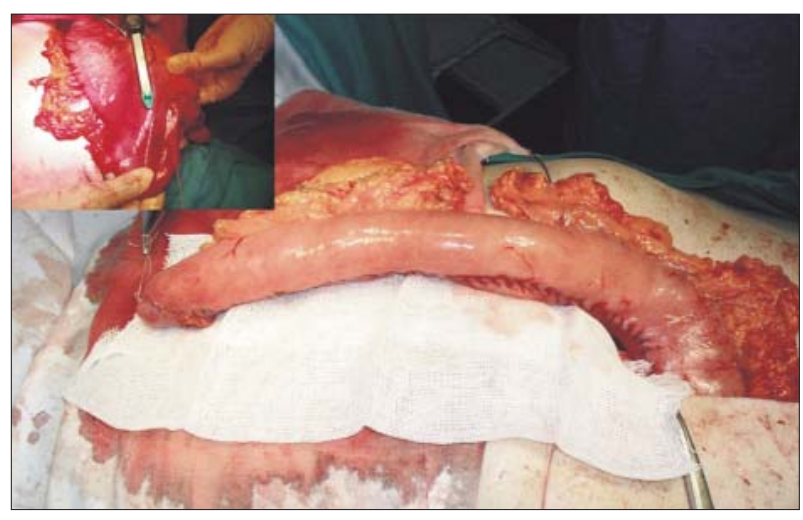

Figure 2. Akiyama procedure - cartridge, graft preparation - main image, finala spect of the graft

A particular type (Table 2) of neuro-motor dysfunction of the esophageal substitute posed particular problems to 6 patients (1 Gavriliu reconstruction and 5 with Nakayama whole stomach), the graft evacuation being difficult, delayed, with significant stasis and food discomfort (vomiting, inability to eat, aspiration phenomena). It is worth noting the lack of piloroplasty in these patients (!). All cases had a quasi-normal oro-pharyngeal swallow, a

Table 2. Postoperative late complications in esophageal reconstruction

\begin{tabular}{lcccc}
\hline Type of complication & Nakayama & Akiyama & Gavriliu & Total \\
\hline Reflux & 5 & 2 & 1 & 8 \\
\hline Motility disorder & 5 & - & 1 & 6 \\
\hline Total & 37 & & & \\
\hline
\end{tabular}




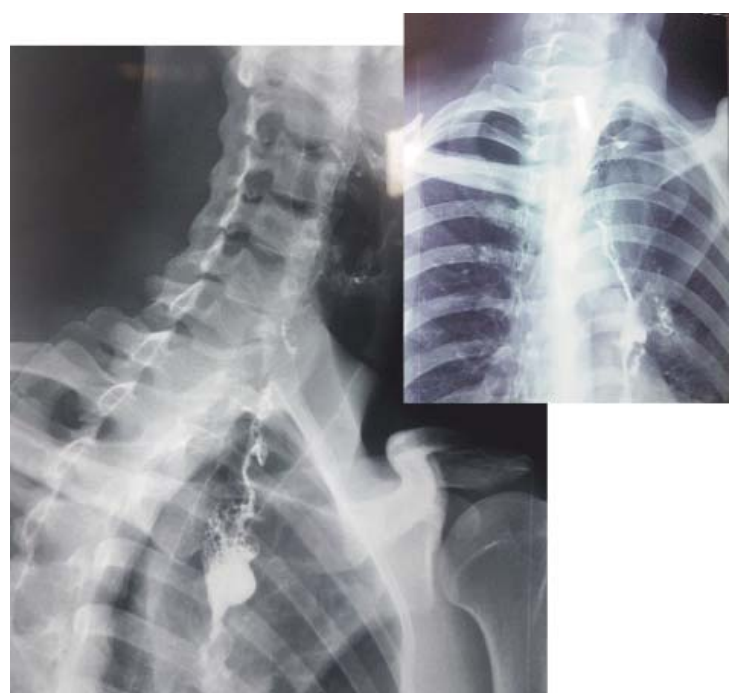

Figure 3. X-ray post-operative control with contrast (lateral view, front view in the cartrige) - Akiyama procedure. Good transanastomotic passage but with delayed evacuation of the graft

permeable cervical anastomosis, a lumen of the free graft, and a stenic but permeable pyloric complex, without obstruction (Figs. 3, 4). Despite the major prokinetics (Erythromycin 2 g/day, Motilium syrup), oligoelement and electrolyte intake, the passage function was somewhat obtained after a long period of follow-up (7-8 months). The gesture that finally corrected the symptoms was endoscopic pilor dilation, repeated for two or three times.

In our group, the reflux pathology (Table 2) was occasional - 8 patients, showed by a specific

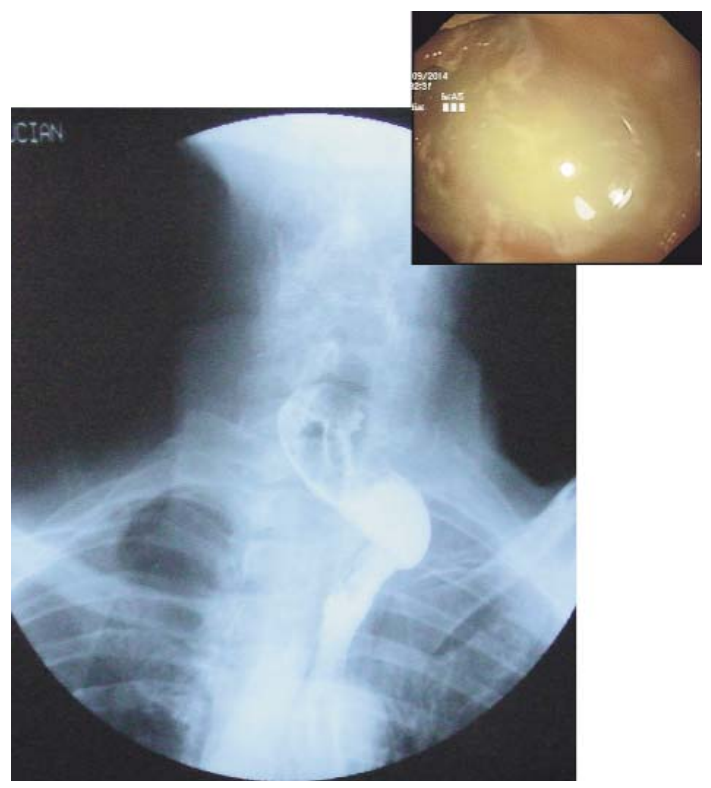

Figure 4. X-ray post-operative control with contrast (front view) - Nakayama procedure. Good transanastomotic passage but with delayed evacuation of the graft. In the cartridge - endoscopic aspect with important stasis in the graft (mixture of barium and gastric juice)

symptoms, barium meal (Figs. 5, 6), endoscopic examination and $\mathrm{pH}-m$ etric examination (Fig. 7). Reflux was alkaline in 7 patients, all with pyloroplasty, 5 with whole stomach and 2 with Akiyama procedure, and in 1 case with Gavriliu procedure the reflux was acid. Of course, a debate on the etiology and the character of reflux is aiming, on the one hand, the alteration of the gastric clearance, i.e. the
Figure 5. Contrast X-ray control - whole stomach reconstruction, Nakayama procedure. Good deglutition, without hesitation. Important reflux in hypopharynx
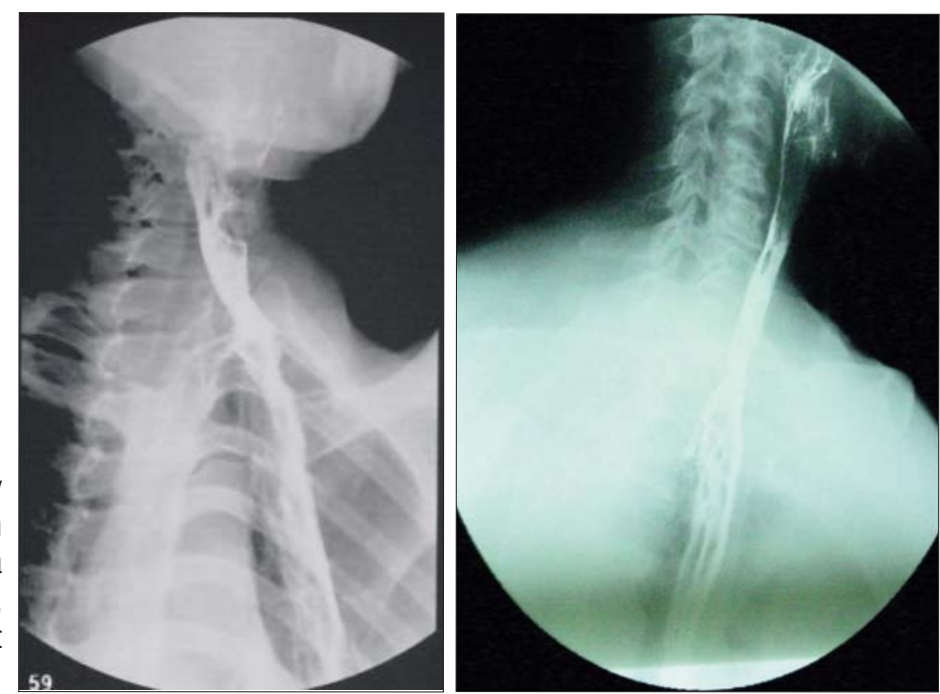

Figure 6. Contrast

X-ray - esophageal reconstruction Gavriliu procedure. Important reflux postadministration 


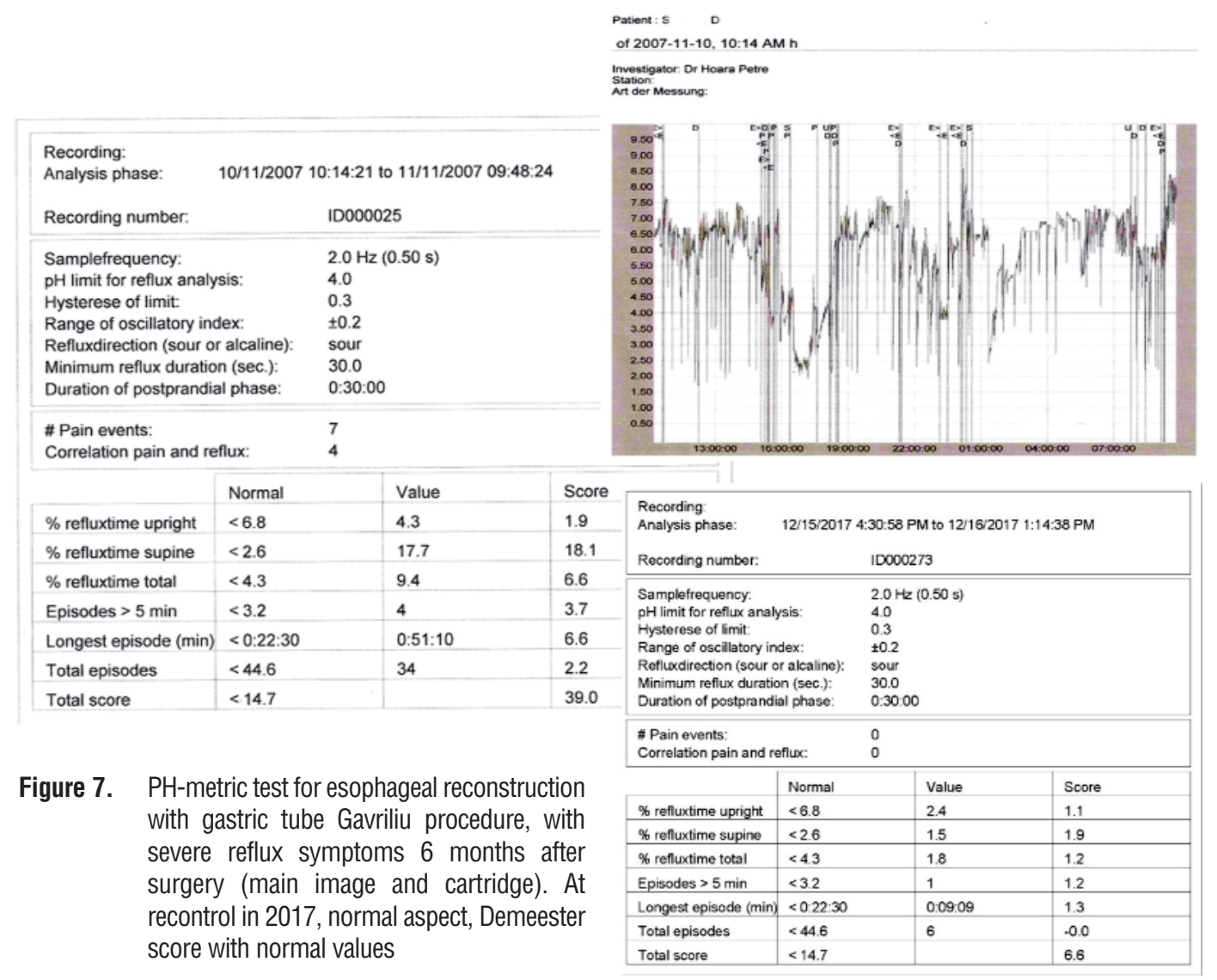

phenomenon of the late evacuation of the graft, and on the other hand the changes in gastric secretion after bilateral troncular vagotomy and last but not least the consequences on the barrier against bilioduodenal pancreatic juice after pyloroplasty. All patients received protective medication (alginate derivatives) or variants such as Sucralfate, H2 receptor inhibitors or proton pump inhibitors, of which they remained dependent for a prolonged period, alternating between treatment and rest periods, and with good long-term results.

\section{Discussion}

These functional complications after gastric reconstruction, mainly motility complications and secondary secretory justify the attention given to the effects of the surgery on the gastric reservoir.

The stomach is characterized by the presence of organized motility in three non-

peristaltic sequential phases, partially under vagal control: gastric fundus, antral and pyloric. Fornixian activity, the first functionally involved gastric region, is initially characterized by an adaptive relaxation moment following ingestion, followed by a progressive increase in tonicity with the propulsion of the content to the antral region. From this moment on, the antral activity of trituration and mixing of food is triggered, followed by the simultaneous initiation of an intermittent propulsive activity with a peristaltic character. The pyloric phase will control gastric evacuation, the oscillation of the pilor between contraction and relaxation being determined by intragastric pressure peaks (secondary to the maximization of propulsive contraction waves of the stomach). If this is the motor behavior in normal conditions, of course it is questionable how will this change and what effects will have the transposition as an esophageal substitute. The answer comes from the post-surgical state: the vagotomy (the 
lack of extrinsic control) and significant decrease of tissue perfusion, especially in the surgical isoperistaltic montage. Their consequences result in serious alterations of the two essential gastric functions $(1,2)$, namely, the secretion and the motility of the stomach, leading to the occurrence of a secondary symptoms (for example, motor dysfunction will cause a reflux or prolonged stasis).

The classic view (3-5), which prevailed for a long time and was based on the motor response of the transplanted stomach, claimed that its functionality was neglectable and behaved as an inert organ. As a consequence, the food passage through the graft is eminently a result of the gravitational effect. Because we have found, as well as other authors $(6,7)$, a good digestive comfort in patients who undergo periodic clinical-paraclinical assess ${ }^{-}$ ments (barium meal, scintigraphic studies) long time after surgery, there was a serious doubt regarding this concept.

In addition, the identification of peristaltic waves on the transplanted stomach on the $\mathrm{X}$-ray screen $(8,9)$ has strengthened our belief that there is a motor activity of the graft.

All these controversies stimulated the study of both secretory ( $\mathrm{pH}$-metric) and motility gastric functions (manometry, electrogastrography), resulting in very interesting results (10-14). Thus, regarding the secretory function, there was a progressive increase in both quantitative and qualitative acido-peptic secretion, resulting after 3 years from surgery a $\mathrm{pH}$ profile $/ 24 \mathrm{~h}$ similar to the control subjects. The data are similar with those obtained from other studies $(15,16)$, confirming the return to normal $\mathrm{pH}$ values in vagotomized patients (BTV) for ulcer.

This evolution can not be attributed to an intra-gastric accumulation of acid secondary to motility disorders after BTV because, after a while, an improvement in gastric emptying occurs through a recovery of antral motor function. In what ways and, of course, who is responsible for this attenuation of gastric dysfunction in time? Is the vagus nerve so important in the functioning of the stomach?

At this point it is revealed $(17-19)$ that vagal fibers do not have a direct connection with the submucosal plexus but ends in the myenteric plexus, especially the one disposed along the grater gastric curves, whereby the vagal impulses reach the submucous plexus only on the path of the myenteric lymph node $(20,21)$.

The relative independence of the enteric nervous system can be somewhat compared to a partially autonomous "brain" that contains the "program" required for the functioning of both secretory and motor activity and outside extrinsic nervous control $(22,23)$.

BTV completely disconnects the connection with control systems in the central nervous system, involving ultrastructural changes that have proved to be reversible in the myenteric neurons and in the secretory cells. The first evidence of normal morphological structural restoration and independence from external inputs is electronomicroscopically identified and confirmed by $\mathrm{pH}$-metric evaluation/ $24 \mathrm{~h}$ $(16,24-26)$.

The second evidence is based on the tracking of peristaltic behavior by manometric and electro-gastrographical studies. What were the parameters tracked and what changes were recorded in normal subjects versus patients with stomach transposition? The manometry identifies pressure waves reflecting contractile activity in control subjects, the pressure variation is recorded at a rate of 3 cycles per minute and corresponds to the electrical discharge rate in the gastric pacemaker. The pressure waves are of two types: macro-waves (amplitude $>9$ $\mathrm{mmHg}$ ) and micro-waves (amplitude $<9 \mathrm{mmHg}$ ). The macro-waves are also subclassified into three categories based on amplitude: 9-50 $\mathrm{mmHg}, 50-200 \mathrm{mmHg}$ and $>200 \mathrm{mmHg}$. Their study allowed the definition of three motility patterns: phase I - a period without macro-waves and which lasts more than 10 minutes, phase II - a period with less than 3 macro-waves/ min and which stretches over a period longer than 10 minutes, phase III - a period of at least 3 or more of macro-waves/min lasting at least 2 minutes. Phase I corresponds to the interdigestive period in which macro-waves are virtually missing, but only micro-waves are recorded. The motili- 
ty pattern characteristic of the feeding period corresponds to phase II, with onset in the same time with the food intake and continuing an estimated time of about 60 minutes. Phase II detects a micro- and macro-wave mix. Phase III, post-alimentary, is characterized by the appearance of high-amplitude macro-waves. In order to facilitate the evaluation of the stomach motility, a unique coefficient was defined as the motility index, which is the sum of the regions with macro waves divided by the time (in minutes) of the most active contractile period. What early postoperative (27-31) motility changes are reported after gastric transposition? First, on the denervated and ascended stomach, the frequency of macro-waves with high amplitude (> $200 \mathrm{mmHg}$ ) decreases both in the alimentary phase (II) and in post-ingestional phase (III), but also the intermediate amplitude macrowaves $-200 \mathrm{~mm} \mathrm{Hg}$ ) during feeding. Second, an atypical presence or even an atypical exaggeration of the micro-wave frequency is noted but with a significant drop in electrical amplitude (relation between BTV - gastric transposition and micro-wave changes is not well known).

This behavior is a mimetic of a heart rhythm disorder, with more or less important of the pump inefficiency. In other words, there is a vicious motor behavior of the gastric graft, somewhat similar to a fibrilatory cardiac motor activity, due to extrinsic electrical deconection, controlled only by the intrinsic component, especially in phases II and III $(5,32)$.

With all these modifications, the motor impact is not always sanctioned by a secondary symptoms but, instead, in those with any clinical manifestation, the pattern of motility is certainly severely altered. The paraclinical expression of causality is evidenced by a significant collapse of the index of motility compared to the control groups, even in comparison to the patients with surgery but not having a specific symptoms. The stomach has a anarchic motility activity, without "coherence," with a "frivolous" intensity and insignificant propulsive force. This typical behavior of the vagotomized graft is called tahigastria. Correlation $(33,34)$ between alteration of relocated stomach motility and delayed gastric emptying is more a result of gastric propulsion dysfunction and not vice versa.

Changing the contractillity pattern of the stomach led to the study of the generating function of the contraction: electrical activity. The widely accepted investigation $(12,35,36)$ is that of electrogastrographic recording, i.e. the electrical signal generated by the stomach (the similarity with the ECG exam is obvious, as is the way of recording with cutaneous electrodes). The parameters that are evaluated and tracked are : (i) dominant frequency (DF) - he frequency with the highest amplitude in conditions of slow gastric waves that can cause contraction, (ii) dominant power (DP) - the highest power of the DF, (iii) power ratio (PR) - ratio between DP pre- and postprandial. Under normal, non-pathological or non-iatrogenic conditions, the characteristic aspect is the one called normogastria and consists of slow, normal-looking, released at a frequency of 2-4 / $\mathrm{min}$. Whenever there are changes to this normal electrical pattern, we are in the face of a gastric dysritmia: bradigastria - when DF of slow wave has a release rate of less than $2 / \mathrm{min}$ and tahigastria - when the rate is somewhere between 4-9 / min (37). Particular for gastric transposition, what can be observed for the early postoperative period? First, normogastria is found in the population at a rate of around $80 \%$, while in gastric transposition the percentage is somewhere between $45-40 \%$. Secondly, bradigastria has a $10 \%$ rate in the control population and about $35 \%$ after surgery and tahigastria approximately $8 \%$ versus about $20 \%$ in surgical patients. Significantly, the pre- and postprandial measurements $(14,37)$ did not significantly alter these indices.

Interpreting the results, we find that isoperistaltic gastric montage has almost normal electro-motor activity in 1 out of 2 operated patients. This explains the existence of operated patients without symptoms caused by motility gastric dysfunctions (early satiety, delayed evacuation, postprandial meteorism, regurgitation, vomiting, dysphagia, reflux, etc.). Transposition of the entire stomach will 
generally produce in the post-alimentary period a drop in the motility index to about $60 \%$ of the normal value, and in the case of tubularization even 54\%. What is interesting to note is that in the prandial phase, the index of motility decreases for those with the whole stomach also with somewhat similar value (64\%), but in those with gastric tube the decrease is insignificant (!) of $87 \%$. Meaning that the motor adaptation of the gastric tube to the food passage is much better compared to the whole stomach, but worse in the postprandial period.

For symptomatic patients, the DF increases significantly in the feeding period in control subjects, while in surgical patients it does not appear to change. Similarly is the PR trend in the post-alimentary period, when its value increases significantly in the control group but not in the surgical patients. These changes in electrical function will determine the presence of a contractile but disritmatic behavior of the graft - tahi- or bradygastria - thus inefficient as propulsive activity. Parameter comparisons only between surgery patients - symptomatic versus non-symptomatic - showed that tahigastria makes the difference between lots at a ratio of $1 / 3$. The tahigastric fraction of non-symptomatic patients is similar to the healthy population. The conclusion emerging from the above is particularly clear: the gastric motor activity is most affected in phases II and III (prandial and postprandial) caused by the loose of superior neuronal control and the temporary inability to suppress it by locally, intragastric " brain ". The consequence of this disconnection will result in locally waves fromation but with frequency, amplitude and vicious distribution. The result is a serious cahnge in the gastric motor pattern, with the generation of weak contractions (below $50 \mathrm{~mm}$ $\mathrm{Hg}$ ) and the occurrence of motor failure manifestations.

Unfortunately we do not know why these changes are significant only in some patients, which is the cause of this discrimination and why only some of them are have a typical symptoms.

Interesting to follow is the modification of gastric motility depending on the diameter of the reconstructive graft $(38,39)$. Thus, strictly comparing the type of reconstructive procedure - whole stomach versus gastric tube - evacuation is delayed in less than $5 \%$ of cases in those with gastric tube versus $35-40 \%$ when the whole stomach was used. Caution, however, could be the at least partial maintenance of vaginal threads during tubulation compared to BTV in the mobilization of the entire stomach.

Extensive manometric and electrogastrographic studies of the gastric tube (40-42) suggest behavior of preservation og the baseline electrical activity, pacemaker activity or electrogastrographic activity and motor activity, a cause of visceral capability as an esophageal substitute.

Particularly interesting is the evolution in time after surgery of the electro-motor function of the gastric graft. Over time, there is a progressive increase in the amplitude of contractions, with the spontaneous recurrence of peristalsis and the three phases of the migratory motor complex. Recovery, however, is slow, long time the transplanted stomach has a poor motor function in the moment of food passage but recovers and behaves much faster and better in the post-prandial period. This would suggest that the distal vagal fibers of the Latarjet nerve are the most important in supporting motor activity.

The impact of improving motor function will be translated into improving food comfort reducing the feeling of early satiety, normalized nutrition, decreasing the number of meals, etc. Early prokinetic administration (ex. eritromycin) seems to dramatically accelerate this restorative process (43-44).

In spite of this recovery, the phenomenon is virtually never complete, revealing that the index of motility is diminished, even in asymptomatic patients. I think it is worth mentioning that the modification of the symptomatic lasymptomatic ratio from $2 / 3$ in the first year to 1/3 after two years. Collard reports a recovery of contractile activity as close to normal as possible beyond three years (!). If we look at the cases reported by us (45), we find the same thing, the symptoms of post-grafting motor 
damage improving in time.

Also important is the behavior depending of the type of substituent. Restored motility is more rapidly found in those with the whole stomach. In addition, the loss of highamplitude macro-waves ( $>200 \mathrm{mmHg}$ ) seems easier to compensate for in these patients as well. The Akiyama resection of the lesser curvature or at least the section of the gastric body during the Gavriliu procedure seems to destroy totally, or at least partially, both the organizer and the motor effector, namely the myenteric plexus and the antral muscle mass. The nervous fibres as well as the interneuronal links will be cut off when performing gastric tubulisation, disconnecting the plexus network from functioning as a whole and resulting a motor disynergy between the two gastric segments (46).

It should be remembered that in Gavriliu procedure the assembly is even more affected by anisoperistaltic placement. So I think this can explain the much weaker response to motilide (erythromycin) stimulation of those with gastric tube reconstruction (43).

An important role in evacuation is also attributed to gravity, especially in the initial period. After 3 years from the surgery, its importance is significantly reduces so that the acidity level is maintained constant regardless of the patient's position, orthostatism or clinostatism.

Even though between the two phenomena secretory activity and motor activity - there is a similarity in restoring a normality over time, it does not occur concurrently. The more rapid recovery of secretory function on the denervated stomach is most likely the reflection of a selfreorganization of the submucosal plexus whose architecture is much less complex compared to that of the myenteric plexus $(47,48)$. It is no less true that the dependence of submucosal plexus on vagal stimuli is much lower compared to that of the myenteric plexus.

Concluding, can we, at least for the time being, answer the question "is reconstruction with a stomach and its variants a reasonable technical solution? And if so, is it preferable to use one procedure or another?

As for the first question, the answer is extremely simple: Yes, the esophageal reconstruction with the stomach and its variants is and will remain a serious alternative to colon recosntruction.

As to the second question, the answer is a bit more nuanced. A number of pathological and morpho-functional limitations make the difference. For malignancy, for both oncological and technical reasons, Nakayama and Akiyama seem to be the best solutions. Instead, in cases of post-caustic stenosis, the two procedures are disqualified by another problem that should not be neglected: providing a drainage pathway for the stenotic esophagus, often through an eso-jejunal anastomosis that will further complicates the operator's gesture. Not performing the drainage operation $(49,50)$ is likely to lead to the cystic transformation of the mediastinal esophagus with severe complications. An alternative would be subtotal esophageal resection with gastric transposition in mediastinum, but perisophageal fibrotic remodeling is often severe, making the esofagectomy extremely difficult.

From a morpho-functional point of view, motor recovery and secretory damage are much better compensated on short term in the use of Gavriliu tubing and food comfort will reach a good level relatively fast. Instead, the Nakayama and Akiyama graft recovers the two functions harder, usually 2-3 years postoperatively, but much closer to "homeostasis", so the food intake will be better over time.

Of course, this entire theoretical dissertation associated with fundamental research studies should involve additional clinical trials but, unfortunately, at least for the time being, the small number of cases does not allow for statistically relevant assessments.

\section{References}

1. Hölscher AH, Voit H, Buttermann G, Siewert JR. Function of the intrathoracic stomach as esophageal replacement. World J Surg. 1988;12(6):835-44

2. Mannell A, Hinder RA, San-Garde BA. The thoracic stomach: A study of gastric emptying, bile reflux and mucosal change. $\mathrm{Br} J$ Surg. 1984;71(6):438-41.

3. Moreno-Osset E, Tomas-Ridocci M, Paris F, Mora F, Garcia-Zarza A, Molina R, et al. Motor activity of esophageal substitute (stomach, jejunal, and colon segments). Ann Thorac Surg. 1986;41(5):515-9. 4. Bonavina L, Anselmino M, Ruol A, Bardini R, Borsato N, Peracchia 
A. Functional evaluation of the intrathoracic stomach as an esophageal substitute.Br J Surg. 1992; 79(6):529-32.

5. Morton KA, Karwande SV, Davis RK, Datz FL, Lynch RE. Gastric emptying after gastric interposition for cancer of the esophagus or hypopharynx. Ann Thorac Surg. 1991;51(5):759-763. doi: 10.1016/0003-4975(91)90119-B. Epub 2015 Sep 27.

6. Collard JM, Otte JB, Reynaert M, Kestens PJ. Quality of life three or more years following esophagectomy for cancer. J Thorac Cardiovasc Surg. 1992;104(2):391-4.

7. Collard JM1, Tinton N, Malaise J, Romagnoli R, Otte JB, Kestens PJ. Esophageal replacement: gastric tube or whole stomach? Ann Thorac Surg. 1995; 60(2):261-6; discussion 267.

8. Huang GJ, Wang LJ, Liu JS, Cheng GY, Zhang DW, Wang GQ, et al. Surgery of esophageal carcinoma. Semin Surg Oncol. 1985;1(2): 74-83.

9. Huang GJ, Zhang DC, Zhang DW. A comparative study of resection of carcinoma of the esophagus with and without pyloroplasty. In Demeester TR, Skinner DB, eds. Esophageal Disorders: Pathophysiology and Therapy. New York: Raven Press; 1985. p. 383-388.

10. Collard JM, Romagnoli R, Otte JB, Kestens PJ. The denervated stomach as an esophageal substitute is a contractile organ. Ann Surg. 1998:227(1):33-9.

11. Collard JM, Romagnoli R. Human stomach has a recordable mechanical activity at a rate of about three cycles/minute. Eur $\mathrm{J}$ Surg. 2001;167(3):188-94

12. Chen JD, Richards RD, McCallum RW. Identification of gastric contractions from the cutaneous electrogastrogram. Am J Gastroenterol. 1994;89(1):79-85.

13. Smout AJ, van der Schee EJ, Grashuis JL. What is measured in electrogastrography? Dig Dis Sci. 1980;25(3):179-87.

14. Izbéki F, Wittmann T, Odor S, Botos B, Altorjay A. Synchronous electrogastrographic and manometric study of the stomach as an esophageal substitute. World J Gastroenterol. 2005:11(8):1172-8.

15. Siewert JR, Hölscher AH. 20 years of vagotomy: indications and choice of procedure--duodenal ulcer. Zentralbl Chir. 1986;111(16): 953-66. German

16. Romeo G, Giovinetto A, Sanfilippo G, Calì R, Catania G, Basile F Follow-up study in 402 patients after parietal cell vagotomy for duodenal ulcer. Int Surg. 1981;66(4):303-6.

17. Kirchgessner A, Gershon MD. Identification of vagal efferent fibers and putative target neurons in the enteric nervous system of the rat. J Comp Neurol. 1989;285(1):38-53.

18. Berthoud HR, Jedrzejewska A, Powley TL. Simultaneous labeling of vagal innervation of the gut and afferent projections from the visceral forebrain with dil injected into the dorsal vagal complex in the rat. J Comp Neurol. 1990;301(1):65-79.

19. Schofield GC Experimental studies on the myenteric plexus in mammals. J Comp Neurol. 1962;119:159-85.

20. Cooke HJ. Role of the "little brain" in the gut in water and electrolyte homeostasis. FASEB J. 1989;3(2):127-38.

21. Kirchgessner AL, Gershon MD. Projections of submucosal neurons to the myenteric plexus of the guinea pig intestine: in vitro tracing of microcircuits by retrograde and anterograde transplant. J Comp Neurol. 1988;277(4):487-98.

22. Andrews PLR, Bingham S. Adaptation of the mechanisms controlling gastric motility following chronic vagotomy in the ferret. Exp Physiol. 1990;75(6):811-25.

23. Christensen J. The enteric nervous system. In: Kumar D, Wingate D, eds. An illustrated guide to gastrointestinal motility. Edinburgh: Churchill Livingstone; 1993. p. 10-31.

24. Vaithilingam UD, Wong WC, Ling EA. Transneuronal changes in the myenteric ganglia of the monkey following vagotomy. Neuroscience. 1986;17(3):829-36.

25. Gutschow C, Collard JM, Romagnoli R, Salizzoni M, Hölscher A Denervated Stomach as an Esophageal Substitute Recovers Intraluminal AcidityWith Time. Ann Surg. 2001;233(4):509-14.

26. Okada N, Nishimura 0, Sakurai T, Tsuchihashi S, Juhri M. Gastric functions in patients with the intrathoracic stomach after esophageal surgery. Ann Surg. Ann Surg. 1986;204(2):114-21.

27. Stoddard CJ, Smallwood R, Brown BH, Duthie HL. The immediate and delayed effects of different types of vagotomy on human gastric myoelectrical activity. Gut. 1975;16(3):165-70.
28. Nelsen TH, Eigenbrodt EH, Keoshian LA, Bunker C, Johnson L. Alterations in muscular and electrical activity of the stomach following vagotomy. Arch Surg. 1967;94(6):821-35.

29. Jansson G, Lisander B. On adrenergic influence on gastric motility in chronically vagotomized cats. Acta Physiol Scand. 1969;76(4): 463-71.

30. You CH, Chey WY. Study of electromechanical activity of the stomach in humans and in dogs with particular attention to tachygastria. Gastroenterology. 1984;86(6):1460-8.

31. You CH, Lee KY, Chey WY, Menguy R. In vitro myoelectric study of antral muscle from the patients of tachygastria. Dig Dis Sci 1980; 25:17.

32. Hinder RA, Kelly KA. Human gastric pacesetter potential: site of origin, spread, and response to gastric transection and proximal gastric vagotomy. Am J Surg. 1977;133(1):29-33.

33. Hocking MP. Postoperative gastroparesis and tachygastriaresponse to electric stimulation and erythromycin. Surgery. 1993;114(3):538-42.

34. Schippers E, Vantrappen G, Braun J, Schumpelick V. Electromyographic and manometric studies of stomach motility after vagotomy. Z Gastroenterol. 1991;29(11):581-4. German

35. Lindberg G, Iwarzon M, Hammarlund B. 24-h ambulatory electrogastrography in healthy volunteers. Scand J Gastroenterol. 1996; 31(7):658-64.

36. Pfaffenbach B, Adamek RJ, Kuhn K, Wegener M. Electrogastrography in healthy subjects. Evaluation of normal values, influence of age and gender. Dig Dis Sci. 1995;40(7):1445-50.

37. Chen JZ, McCallum RW. Electrogastrographic parameters and their clinical significance. In: Chen JZ and McCallum RW, eds. Electrogastrography: Principles and Applications. New York: Raven Press, Ltd; 1994. p. 45-73.

38. Bemelman WA, Taat CW, Slors JF, van Lanschot JJ, Obertop H. Delayed postoperative emptying after esophageal resection is dependent on the size of the gastric substitute, J Am Coll Surg. 1995;180(4):461-4

39. Terashima T, Homma S, Watanabe N, Maruta T, Hasegawa J, Hatakeyama K. Motor and electrogastrographic activity of the gastric tube formed after esophagectomy J Smooth Muscle Res. 2005;41(2):99-106

40. Homma S, Shimakage N, Yagi M, Hasegawa J, Sato K, Matsuo H, et al. Electrogastrography prior to and following total gastrectomy, sub-total gastrectomy, and gastric tube formation. Dig Dis Sci. 1995;40(4):893-900.

41. Malgelada JR, Camilleri M. and Stanghellini V. Manometric diagnosis of gastrointestinal motility disorders. New York: Thieme; 1986.

42. Logeman F, Roelofs JM, Obertop H, Akkermans LM. Tonic motor activity of the narrow gastric tube used as an oesophageal substitute. Eur J Surg. 2000;166(4):301-6.

43. Collard JM, Romagnoli R, Otte JB, Kestens PJ. Erythromycin enhances early postoperative contractility of the denervated whole stomach as an esophageal substitute. Ann Surg. 1999:229(3): 337-43

44. Burt M, Scott A, Williard WC, Pommier R, Yeh S, Bains MS, et al. Erythromycin stimulates gastric emptying after esophagectomy with gastric replacement: a randomized clinical trial. J Thorac Cardiovasc Surg. 1996 ;111(3):649-54.

45. Predescu D, Constantinoiu S. Problems and difficulties in patients with esophageal reconstruction. Chirurgia (Bucur). 2002;97(2):187-201.

46. Wattchow DA, Brookes SJH, Costa M. The morphology and projections of retrogradely labeled myenteric neurons in the human intestine. Gastroenterology. 1995;109(3):866-75.

47. Mannell A, McKnight A, Esser JD. Role of pyloroplasty in the retrosternal stomach: results of a prospective, randomized, controlled trial. Br J Surg. 1990;77(1):57-9.

48. Collard JM, Romagnoli R, Otte JB, Kestens PJ. The denervated stomach as an esophageal substitute is a contractile organ. Ann Surg. 1998; 227(1):33-9.

49. Kamath MV, Ellison RG, Rubin JW, Moore HV, Pai GP. Esophageal mucocele: a complication of blind loop esophagus. Ann Thorac Surg. 1987;43(3):263-9.

50. Gerzic ZB, Knezevic JB, Milicevic MN, Jovanovic BK. Esophagocoloplasty in the management of postcorrosive strictures of the esophagus. Ann Cardiothorac Ann Surg. 1990;211(3):329-36. 